\title{
Construction particleboards made from rapeseed straw glued with hybrid pMDI/PF resin
}

\author{
Dorota Dukarska $^{1}\left({ }^{10} \cdot\right.$ Rafał Czarnecki $^{1} \cdot$ Dorota Dziurka $^{1} \cdot$ Radosław Mirski $^{1}$
}

Received: 8 March 2016 / Published online: 16 December 2016

(C) The Author(s) 2016. This article is published with open access at Springerlink.com

\begin{abstract}
The paper investigates the possibility of manufacturing rapeseed particleboards (RPB) which could be used as construction material in eco buildings. Therefore, single-layer particleboards were produced from rapeseed straw particles glued with mixture of 4.4'-methylenediphenyl isocyanate (pMDI) and phenol-formaldehyde (PF) resins in the weight ratio 70:30 (hybrid pMDI/PF resin). The boards were manufactured with density of $650,600,550$, 500 and $450 \mathrm{~kg} / \mathrm{m}^{3}$. Next, their physico-mechanical properties were determined, i.e. modulus of rupture, modulus of elasticity, internal bond and internal bond after the boil test (V-100) and thickness swelling after $24 \mathrm{~h}$ soaking in water. The thermal conduction coefficient $(\lambda)$ and sorption properties in changeable relative humidity conditions were also determined. Based on the obtained results, it was found that rapeseed straw may be a valuable material used in the production of construction particleboards which meet high strength requirements. Boards with density of $650 \mathrm{~kg} / \mathrm{m}^{3}$ meet the requirements of EN 312 standard for type $\mathrm{P} 7$ boards. It is also possible to decrease their density to $600 \mathrm{~kg} / \mathrm{m}^{3}$ (type P5 boards) and even $550 \mathrm{~kg} / \mathrm{m}^{3}$ (type P3 boards). However, rapeseed particleboards are characterized by relatively high values of thickness swelling after $24 \mathrm{~h}$ of soaking in water. The weaker resistance to humidity has also been confirmed by tests on sorption and desorption of vapour in changeable relative humidity conditions. Nonetheless, an important advantage of these boards is the
\end{abstract}

Dorota Dukarska

ddukar@up.poznan.pl

1 Department of Wood Based Materials, Faculty of Wood Technology, Poznan University of Life Sciences, ul. Wojska Polskiego 38/42, 60-627 Poznan, Poland fact that they are characterized by better thermal insulation than particleboards.

\section{Introduction}

Owing to their physical and mechanical properties, construction particleboards are used as wall, floor, ceiling and roof covering as well as finishing and insulating material. Particleboards are also the basic material for interior furnishings used in increased humidity conditions (http:// www.pfleiderer.pl). Therefore, phenol-formaldehyde resin is the most commonly used adhesive as it provides products with high strength and resistance to various weather conditions. The resin is also characterized by high thermal resistance, low susceptibility to hydrolysis and low formaldehyde emission. However, the resin has low reactivity which necessitates for the cross-linking process to be conducted at very high temperatures. Moreover, from the aesthetic point of view, the dark colour of the adhesive joint is a drawback. So far, a number of research projects have been carried out aimed at increasing the reactivity of phenolic resins through proper selection of substrates, mole ratio of reagents and condensation conditions as well as through introducing modifiers into the resin, which are meant to accelerate the cross-linking process (Park et al. 1999; Conner et al. 2002; Dukarska and Łęcka 2006; Mirski et al. 2008, 2011; Zhang et al. 2013). Phenolic resins, just like amine resins, join surfaces through adhesion. In the case of gluing particles of annual plant waste (mainly grain straw), the presence of waxy substances on their surface considerably decreases the adhesion of the resin, which deteriorates the strength and water resistance of the boards. This problem can be solved by using pMDI (polymeric methylene diphenyl-di-isocyanate) resins. Isocyanate pMDI resins join 
the lingocellulose particles by the reaction of isocyanate groups $-\mathrm{N}=\mathrm{C}=\mathrm{O}$ with $-\mathrm{OH}$ groups of mainly cellulose and lignin. As a result, urethane bonds $-\mathrm{NH}-\mathrm{CO}-\mathrm{O}-$ are created. Owing to such a gluing mechanism, the pMDI adhesive joints show higher values of strength and water resistance properties than amine and phenolic resins commonly used in wood products industry. Another advantage of pMDI resins is their high reactivity and good surface wettability. However, there are also drawbacks: the resin is expensive and it is characterized by chemical affinity to not only particles of the lignocellulose material but also to other materials, for example metal elements of a production line. That is why, researchers paid closer attention to hybrid resins, i.e. resins which are a combination of cheaper amine or phenolic resins with pMDI glues. Such an option allows for reducing the costs and makes it possible to eliminate the difficulties related with the resin's capacity for gluing other materials. The hybrid resins play an especially important role in the production of boards made from recycled waste (Wang et al. 2007, 2008; Lykidis et al. 2012) or annual plants waste (Grigoriou 2000; Lee et al. 2006; Magzoub et al. 2015). The use of hybrid adhesives will definitely expand the range of possible uses of such boards in building constructions, as it also results from the growing popularity of eco-buildings made from natural materials. An example here is the revival of straw bale houses, especially in the USA, Canada, Australia, Japan and Europe (Vejeliene et al. 2011; Thomson and Walker 2014). According to Goodhew and Griffiths (2005), this building technology provides buildings with better thermal insulation of walls than wood or wood-based materials. It also makes it possible to save the materials and use local resources and, therefore, reduce the costs of transport as well as air pollution (Morel et al. 2001). The investigations made so far on the substitution of wood particles with annual plants waste, have proved that they can be used as a valuable material for the production of particleboards as long as proper production conditions are applied (Dukarska et al. 2015). Based on papers published so far, Müller et al. (2012), made a thorough review of alternative materials which can substitute wood particles in the production of particleboards. They provide a detailed description of their advantages and disadvantages as well as prospects and opportunities of use and challenges which manufacturers have to face. One of the most important benefits is the fact that the discussed materials are renewable, easily available, recyclable, and biodegradable. What is more, they are characterized by a favourable strength to density ratio and they show good thermal and acoustic insulation properties. The major difficulty in applying these materials is their seasonality and poorer wettability by bonding agents than in the case of wood. The authors also pay attention to the fact that the limitations connected with the use of agricultural waste partially result from inefficient knowledge of the chemical and physical properties of these materials. The review of literature on the subject shows that numerous investigations into the substitution of wood chips with particles of annual plants have been carried out so far. Owing to the crop size, researchers focus mainly on the use of wheat straw (Grigoriou 2000; Boquillon et al. 2004; Azizi et al. 2011; Bekhta et al. 2013), rice straw (Li et al. 2010; Zhang and Hu 2014), flax and hemp (Papadopoulos and Hague 2003), kenaf, bamboo (Papadopoulos et al. 2004; Xu et al. 2004), corn, sunflower, various grass species, sugar cane, but also on herbaceous plants, such as evening primrose (Hein et al. 2011; Dukarska et al. 2012; Park et al. 2012; Cosereanu et al. 2015; Guler et al. 2016). Wood particles can also be substituted by tomato stalks and grapevine, kiwi, coffee or tea waste (Nemli et al. 2003; Guuntekin et al. 2009; Bekalo and Reinhardt 2010), which is an interesting option too. The authors of the present paper also notice the possibility of using waste of oil plants, mainly rapeseed straw. Rapeseed is primarily used to attain oil, both edible and technical, but is is also valuable protein feed for animals. The dynamic development of biofuel production has contributed to a considerable growth in the rapeseed cultivation area. Initially, it was assumed that until 2020 the share of biofuels in the EU road transport would reach 10\% (directive 2003/30/EC). Even though in 2015 the predicted share was decreased to $7 \%$, in Europe rapeseed is still the basic biocomponent in the production of biofuels (Van Duren et al. 2015). According to FAOSTAT reports, in 2014 China, Canada and India were the largest producers of rapeseed in the world. As for Europe, it was France, Germany and Russia with net sown area of 1.5, 1.3 and $1.1 \mathrm{mln}$ ha, respectively (FAOSTAT 2016). In the last 5 years there have only been slight changes in these values. It is noticeable, however, that in countries such as Poland, Hungary, Bulgaria and Ukraine the net sown area for rapeseed has grown considerably. As the rapeseed production is growing rapidly, the utilization of waste has become an important issue. Rapeseed straw can be potentially used as a raw material in particleboard production as its chemical constitution is similar to that of wood. Rapeseed straw contains a bit less cellulose and lignin, yet it has more hemicellulose. The amount of extractives is comparable or only slightly higher than in wood. It is significant that unlike cereal straw, in case of rapeseed straw these substances are dispersed throughout the whole mass, which favourably affects the gluability even when typical wood adhesives are used (Dziurka et al. 2005; Dukarska et al. 2011; Dziurka and Mirski 2013).

The review of the literature shows that so far there have been very few publications on the possible use of this material in the production of particleboards which meet the requirements for construction boards. Therefore, it was decided to carry out investigations on the possibility 
of applying rapeseed straw particles to the production of construction particleboards glued with pMDI resin. Taking into consideration the fact that wood products industry shows growing interest in light materials, the possibility of decreasing the density of the boards and its effect on physical and mechanical properties of the rapeseed particleboards were also investigated.

\section{Materials and methods}

In the production of particleboards, particles of rapeseed straw obtained by means of two-stage grinding in a knife grinding machine were applied. The attained straw particles were subjected to dimensional analysis. In order to do so $50 \mathrm{~g}$ of straw particles were selected and then sorted on sieves with mesh size ranging from 0.25 to $3.15 \mathrm{~mm}$. Next, 50 pieces of straw particles were randomly picked from the sieve with $1 \mathrm{~mm}$ mesh size and their length, width and thickness were measured with an accuracy of $0.01 \mathrm{~mm}$. Based on these measurements their slenderness $(\lambda)$ was determined, which is the ratio of average length and average thickness of the straw particles. Next, fatness ratio $(\psi)$ was determined, which is the ratio of average width and average thickness of straw particles, and the width factor (m), which is the ratio of average length and average width of straw particles. This kind of analysis is often used to provide characteristics of materials used in the production of particleboards (Lee et al. 2006; Dukarska et al. 2011; Cosereanu et al. 2015; Dziurka and Mirski 2013) and to determine the effect of particle size on physical and mechanical properties of the manufactured particleboards (Pan et al. 2007; Arabi et al. 2011; Mirski et al. 2013). The results of these analyses are shown in Table 1.

As bonding agent the adhesive made from polymeric 4,4'-methylenediphenyl isocyanate (pMDI) and phenol-formaldehyde resin (PF) was used in the weight ratio 70:30. The properties of pMDI were as follows: solids content $-100 \%$, NCO content- $31 \%$, viscosity at $25^{\circ} \mathrm{C}-220$ Pas and chlorine hydrolytic $-96 \mathrm{mg} / \mathrm{kg}$. PF resin was characterised by viscosity at $25^{\circ} \mathrm{C}-620$ Pas, density-1.215 g/cm ${ }^{3}$, solid content $-46.5 \%, \mathrm{pH}-8.75$ and gel time at $130{ }^{\circ} \mathrm{C}-265$ s. Single-layer rapeseed

Table 1 Dimensional analysis and the shape of average particles of rapeseed straw

\begin{tabular}{llllll}
\hline Parameter & & & & & \\
\hline $1(\mathrm{~mm})$ & $\mathrm{a}(\mathrm{mm})$ & $\mathrm{b}(\mathrm{mm})$ & $\lambda$ & $\psi$ & $\mathrm{m}$ \\
\hline 15.50 & 1.05 & 1.27 & 14.76 & 1.21 & 12.20 \\
\hline
\end{tabular}

$l$ length, $a$ thickness, $b$ width, $\lambda$ slenderness ratio, $\psi$ flatness ratio, $m$ width factor particleboards (RPB) were produced under laboratory conditions. The following parameters of the boards were applied: dimensions $450 \times 700 \times 15 \mathrm{~mm}^{3}$, gluing degree $10 \%$ and density $650,600,550,500$ and $450 \mathrm{~kg} /$ $\mathrm{m}^{3}$. The pressing process was carried out at $200^{\circ} \mathrm{C}$, with unit pressure of $2.5 \mathrm{~N} / \mathrm{mm}^{2}$ and time of $23 \mathrm{~s} / \mathrm{mm}$ of the board thickness. The physical and mechanical properties of manufactured experimental boards were tested according to relevant standards. Modulus of rupture (MOR) and modulus of elasticity (MOE) were determined according to EN 310 (1993), internal bond (IB) according to EN 319 (1993), internal bond after a boil test (V-100) according to EN 1087 and thickness swelling after $24 \mathrm{~h}$ of soaking in water (TS) according to EN 317 (1993). Each test was made in ten replicates. Taking into account the fact that the boards are supposed to be used as covering material, their thermal conduction coefficient $(\lambda)$ was determined with the use of the auxiliary wall method. Hence, a test chamber and a laboratory measuring set was used for determining heat flux density, equipped with a heat flux density sensor type ALMEMO 117 company Ahlborn, with plate dimension $100 \times 30 \times 3 \mathrm{~mm}^{3}$. The chamber is equipped with a heating system which makes it possible to maintain constant temperature difference between the chamber and the environment. The ALMEMO sensor was located in the heat flux flowing through the investigated sample: it was attached to the face side of the board with the use of thermally conductive silicone paste. The heat flowing through the board sample and the sensor cause a temperature difference on the sensor surfaces creating thermoelectric voltage. By measuring this voltage, the density of heat flux was determined according to the equation:

$q=C \cdot U_{r}$

where q-density of heat flux $\left(\mathrm{W} / \mathrm{m}^{2}\right), \mathrm{C}$-calibration coefficient: $35.8\left(\mathrm{~W} / \mathrm{m}^{2} \mathrm{mV}\right), \mathrm{U}_{\mathrm{r}}$-voltage $(\mathrm{mV})$. At the same time, with the use of resistance sensors, the temperature difference on both sides of the investigated particleboard was determined. The measurements were made each time the temperature stabilized on the board surfaces and the voltage reached a constant value. Based on the determined values of heat flux density $q$ and the temperatures of the particleboard surfaces, the value of heat conductivity coefficient was estimated with the use of below equation:

$k=\frac{q}{T_{1}-T_{2}}$

where $\mathrm{k}$ - heat conductivity coefficient $\left(\mathrm{W} / \mathrm{m}^{2} \mathrm{~K}\right), \mathrm{T}_{1}$ - temperature of the board side heated in the chamber $(\mathrm{K}), \mathrm{T}_{2}$ temperature of the face side of the board (K). Taking into consideration the fact that thermal resistance $R\left(m^{2} \mathrm{~K} / \mathrm{W}\right)$ is directly proportional to heat conductivity coefficient $\mathrm{k}$, 
thermal conduction coefficient $\lambda(\mathrm{W} / \mathrm{mK})$ was calculated according to the dependence:

$\lambda=\frac{d}{R}$

where d-thickness of boards. Determining the value of heat conductivity coefficient according to the accepted methodology greatly depends on the environmental conditions. Therefore, the measurements of heat flux density and temperatures on the board surfaces were made five times for each type of the investigated particleboards.

Since heat-insulating properties depend on the moisture content of materials, the moisture sorption at $20^{\circ} \mathrm{C}$ with varied relative humidity of the air was measured with the use of the static desiccator method. Samples of investigated rapeseed particleboards were conditioned over saturated saline solution for 8 weeks. As hygrostatic factors saturated saline solutions were used which allow to attain the proper values of relative humidity (RH) of the air, i.e. $\mathrm{MgCl}_{2}-$ $32 \%, \mathrm{KNO}_{3}-45 \% \mathrm{NaNO}_{2}-65 \%$ and $\mathrm{KCl}-85 \%$. After 8 weeks of seasoning, the samples were weighted and their moisture content was determined. Based on these data the dependence between the sorption properties of investigated particleboards and relative humidity of the air was determined. Therefore, sorption and desorption isotherms were determined as well as differences between these phenomena, expressed as S/D ratio.

Table 2 Physical and mechanical properties of OSB/3 and MFP as stated by their manufacturers

\begin{tabular}{llll}
\hline Property & Unit & OSB/3 & MFP \\
\hline MOR II* & $\mathrm{N} / \mathrm{mm}^{2}$ & 20 & 13.3 \\
MOR $\perp^{* *}$ & $\mathrm{~N} / \mathrm{mm}^{2}$ & 10 & \\
MOE II & $\mathrm{N} / \mathrm{mm}^{2}$ & 3500 & 3300 \\
MOE $\perp$ & $\mathrm{N} / \mathrm{mm}^{2}$ & 1400 & \\
IB & $\mathrm{N} / \mathrm{mm}^{2}$ & 0.32 & $\geq 0.45$ \\
V100 & $\mathrm{N} / \mathrm{mm}^{2}$ & 0.13 & $\geq 0.14$ \\
TS & $\%$ & 15 & $\leq 10$ \\
$\lambda$ & $\mathrm{W} / \mathrm{mK}^{2}$ & 0.13 & 0.12 \\
\hline
\end{tabular}

*Major axis, **lateral axis
In order to provide better characteristics of the manufactured rapeseed particleboards, the results of the tests with regard to physical and mechanical properties were compared with the properties of industrially produced particleboards commonly used in building industry. For this purpose, OSB $/ 3$ boards with a density of $630 \mathrm{~kg} / \mathrm{m}^{3}$ and thickness of $15 \mathrm{~mm}$ (produced by Kronopol, Poland) and MFP boards with a density of $750 \mathrm{~kg} / \mathrm{m}^{3}$ and thickness of $15 \mathrm{~mm}$ (single-layer particleboards, type P5, produced in Poland) were used. Table 2 shows properties of these boards as stated by the manufacturers.

The results of the investigations on the physical and mechanical properties of the experimental boards were statistically analyzed with the use of the programme STATISTICA version 12. To compare the average values of physical and mechanical properties of investigated boards a single-factor analysis of variances was carried out as well as Tukey's post hoc test, which was the basis for determining uniform average values for each of the investigated properties, with the boundary value of significance level equal to 0.05 .

\section{Results and discussion}

Table 3 shows the results of investigations on the physical and mechanical properties of experimental rapeseed particleboards depending on their density. Symbols " $a, b$, c, d" included in the table stand for homogenous groups of averages determined based on post hoc analysis of Tukey's test. Expectedly, the strength properties deteriorated as the density of the boards was decreased. The post hoc analyses also show statistically significant changes in the obtained values. It is especially evident in the case of modulus of rupture, modulus of elasticity and internal bond. According to Tukey's test for homogenous groups for particleboards with a density from 650 to $550 \mathrm{~kg} / \mathrm{m}^{3}$, three groups of parameters $(\mathrm{a}, \mathrm{b}, \mathrm{c})$ were distinguished for which the level of statistical significance $p$ had values lower than the assumed 0.05. The decrease in MOR, MOE and IB observed for particleboards with a density of 600 and
Table 3 Physical and mechanical properties of rapeseed particleboards (RPB)

\begin{tabular}{llllll}
\hline $\begin{array}{l}\text { Density of } \\
\text { RPB }\left(\mathrm{kg} / \mathrm{m}^{3}\right)\end{array}$ & MOR $\left(\mathrm{N} / \mathrm{mm}^{2}\right)$ & MOE $\left(\mathrm{N} / \mathrm{mm}^{2}\right)$ & IB $\left(\mathrm{N} / \mathrm{mm}^{2}\right)$ & $\mathrm{V}-100\left(\mathrm{~N} / \mathrm{mm}^{2}\right)$ & TS $(\%)$ \\
\hline 650 & $20.6(1.65)^{*} \mathrm{a}$ & $3610(230) \mathrm{a}$ & $0.63(0.049) \mathrm{a}$ & $0.21(0.035) \mathrm{a}$ & $14.7(1.79) \mathrm{b}$ \\
600 & $16.3(0.76) \mathrm{b}$ & $3130(110) \mathrm{b}$ & $0.48(0.032) \mathrm{b}$ & $0.17(0.032) \mathrm{c}$ & $14.0(1.35) \mathrm{ab}$ \\
550 & $14.2(0.71) \mathrm{c}$ & $2670(300) \mathrm{c}$ & $0.39(0.027) \mathrm{c}$ & $0.16(0.021) \mathrm{cd}$ & $13.7(1.13) \mathrm{ab}$ \\
500 & $8.5(0.77) \mathrm{d}$ & $1870(160) \mathrm{d}$ & $0.33(0.028) \mathrm{d}$ & $0.14(0.017) \mathrm{d}$ & $13.1(0.42) \mathrm{ac}$ \\
450 & $6.74(0.83) \mathrm{d}$ & $1530(170) \mathrm{d}$ & $0.31(0.032) \mathrm{d}$ & $0.12(0.025) \mathrm{b}$ & $11.6(1.04) \mathrm{c}$ \\
\hline
\end{tabular}

*Standard deviation; $\mathrm{a}, \mathrm{b}, \mathrm{c} .$. homogenous groups according to Tukey's $t$ test $(\alpha=0.05)$ 
$550 \mathrm{~kg} / \mathrm{m}^{3}$ amounts to $30 \%$ for MOR and IB, respectively and 15 and $20 \%$ for MOE. Boards with a density of 450 and $500 \mathrm{~kg} / \mathrm{m}^{3}$ are included in the same homogenous group "d", which means that in terms of strength properties they did not show statistically significant differences. The values of MOR, MOE and IB determined for these boards were 50-70\% lower than those of boards with the highest density. Yet, it is noteworthy that in spite of the decrease in strength properties, the boards with a density of $650-550 \mathrm{~kg} / \mathrm{m}^{3}$ still meet the strict strength requirements for construction particleboards. According to EN 312 (2005) standard, particleboards with a density of $650 \mathrm{~kg} / \mathrm{m}^{3}$ can be classified as P7 type, i.e. boards with increased load-carrying capacity intended for use in humid conditions. When the density is decreased to $600 \mathrm{~kg} / \mathrm{m}^{3}$ the use of the particleboards is limited to conditions intended for P5 type of boards, i.e. boards with load-carrying capacity intended for use in humid conditions. Particleboards with a density of $550 \mathrm{~kg} / \mathrm{m}^{3}$ meet the requirements for boards used as interior furnishings in humid conditions. However, when the density of the boards was decreased to 500 and $450 \mathrm{~kg} / \mathrm{m}^{3}$, the values of MOR, MOE and IB are reduced to a level where it is impossible to use the particleboards as construction material.

The use of hybrid adhesive pMDI/PF made it also possible to attain high values of internal bond after the boil test. Although the test results show a decrease in $\mathrm{V}-100$ value, even particleboards with density reduced to $500 \mathrm{~kg} / \mathrm{m}^{3}$ meet the requirements of EN 312 standard for P5 particleboards (value required by the standard: $0.14 \mathrm{~N} / \mathrm{mm}^{2}$ ). The statistical analysis shows that within this range boards do not show such significant changes in values as in the case of other strength properties. This can be confirmed by the Tukey's test presented in Tables 3 and 4 . Values of V-100 test obtained for particleboards with a density of $550 \mathrm{~kg} / \mathrm{m}^{3}$ are in between values attained for boards with a density of 600 and $500 \mathrm{~kg} / \mathrm{m}^{3}$.

The results of the tests on thickness swelling after $24 \mathrm{~h}$ of soaking in water (TS) are different though. Expectedly, as the density of particleboards was reduced, their thickness swelling decreased after such a long action of water. Particleboards with a density of $600-450 \mathrm{~kg} / \mathrm{m}^{3}$ meet the requirements for $\mathrm{P} 3$ boards: their thickness swelling after
$24 \mathrm{~h}$ of soaking in water should be $14 \%$. For boards with a density of $650 \mathrm{~kg} / \mathrm{m}^{3}$, the TS values exceed $14 \%$, i.e. the level required for particleboards intended for use in humid conditions. The decrease in TS value along with the reduction of board density can be explained by the greater porosity of the structure of boards with lower density. However, when analyzing the attained results, it should be taken into account the fact that the experimental boards had only one layer. Moreover, they did not have the face layers which, due to their higher gluing degree and firmer structure, usually make it more difficult for water to penetrate into the boards. What is more, in the production process no hydrophobic agents were applied, which could reduce the negative effects of a long-time action of water. Just as in the case of other properties, the results of tests on thickness swelling were subjected to statistical analysis which showed that the influence of density on the TS value was not as significant as in terms of strength parameters. These findings were also confirmed by the dispersion diagram of TS value depending on the density (Fig. 1). In case of both V-100 test and thickness swelling, the observed phenomena result

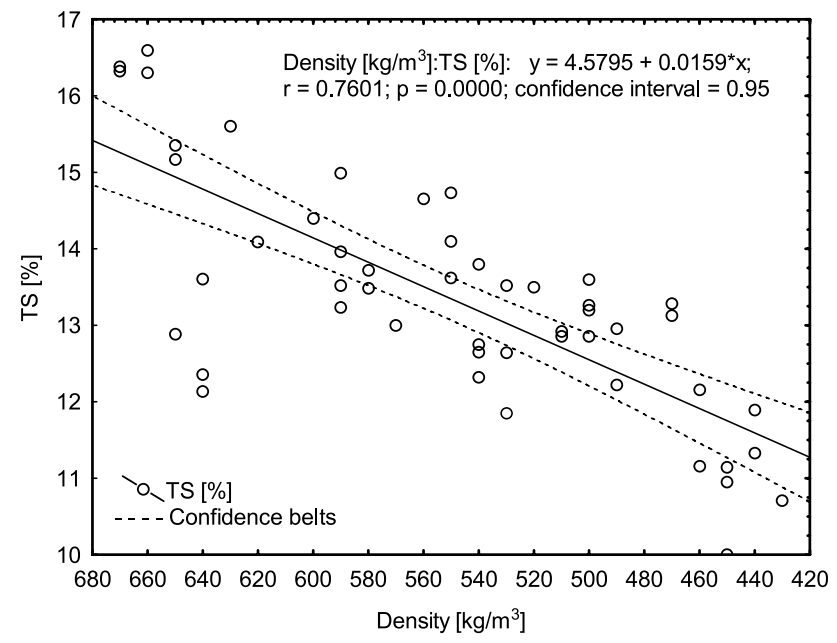

Fig. 1 Dispersion diagram of thickness swelling values after $24 \mathrm{~h}$ of soaking in water depending on the density of rapeseed particleboards (RPB)
Table 4 Results of Tukey's test for internal bond of rapeseed particleboards (RPB) after boil test (V-100)

\begin{tabular}{lllllll}
\hline No. & $\begin{array}{l}\text { Density of } \\
\text { RPB }\left(\mathrm{kg} / \mathrm{m}^{3}\right)\end{array}$ & $\{1\} 0.12555$ & $\{2\} 0.14579$ & $\{3\} 0.15747$ & $\{4\} 0.16972$ & $\{5\} 0.20762$ \\
\hline 1 & 450 & - & 0.001598 & 0.000134 & 0.000134 & 0.000134 \\
2 & 500 & 0.001598 & - & 0.141929 & 0.000271 & 0.000134 \\
3 & 550 & 0.000134 & 0.141929 & - & 0.111615 & 0.000134 \\
4 & 600 & 0.000134 & 0.000271 & 0.111615 & - & 0.000134 \\
5 & 650 & 0.000134 & 0.000134 & 0.000134 & 0.000134 & - \\
\hline
\end{tabular}

HSD Tukey's test; intergroup MS-0.00013, $\mathrm{df}=45.000$ 
from the durability and water resistance of the adhesive joints. Owing to these factors, along with the good cohesion of the boards, the density of the boards has modest effect on their internal bond after a boil test and thickness swelling.

The comparison of properties of rapeseed particleboards and industrially produced $\mathrm{OSB} / 3$ and MFP boards (Table 2) leads to the conclusion that in terms of resistance RPBs have comparable or even better properties than the minimum values stated by the manufacturers of $\mathrm{OSB} / 3$ and MFP. The values of modulus of rupture and modulus of elasticity for rapeseed particleboards with a density of $650 \mathrm{~kg} / \mathrm{m}^{3}$ are comparable to those for OSB $/ 3$ in the so called larger axis, i.e. parallel to the board surface. In relation to MFP, rapeseed boards show much higher values of MOR. It is also noteworthy that RPBs are characterized by high values of IB and V-100 test when compared to both industrially produced types of boards. Rapeseed particleboards with density of $650 \mathrm{~kg} / \mathrm{m}^{3}$ show twice as high values of internal bond determined both before and after $\mathrm{V}-100$ test than the minimum values stated for OSB/3. When compared with MFP, the values are 50 and $40 \%$ higher, respectively. Only when the density of RPBs was decreased to $600 \mathrm{~kg} / \mathrm{m}^{3}$ these values were reduced to the level comparable with that for MFP. If thickness swelling after $24 \mathrm{~h}$ of soaking in water is taken into consideration, PRBs show values comparable to those for commonly used $\mathrm{OSB} / 3$, yet these values are much higher than those stated for MFP. Although it seems a relatively high value, it must be emphasised that in the production of RPBs no hydrophobic agent was used, unlike in the case of industrially produced boards.

The applied auxiliary wall method is one of the basic methods for measuring heat flux density. It is used to determine thermal insulation or thermal resistance of construction materials in both laboratory and field conditions. Values of heat conductivity coefficient $\lambda$ for rapeseed particleboards depending on their density, presented in Fig. 2, allow for drawing conclusions concerning their thermal insulation. Expectedly, there is a close relationship between the density of investigated experimental particleboards and their thermal insulation. Heat-insulating properties of materials depend on numerous factors, such as density (Xu et al. 2004), humidity (Yu et al. 2011), thickness (Kawasaki and Kawai 2006; Sonderegger and Niemz 2009), ambient temperature, heat flow direction, size and geometry of particles and the board structure (Wei et al. 2015; Cosereanu et al. 2015). As Fig. 2 shows, the measured values of $\lambda$ range from $0.008 \mathrm{~W} / \mathrm{mK}$ for boards with density of $650 \mathrm{~kg} / \mathrm{m}^{3}$ to $0.065 \mathrm{~W} / \mathrm{mK}$ for boards with density of $450 \mathrm{~kg} / \mathrm{m}^{3}$. It is noteworthy that boards with density of $650 \mathrm{~kg} / \mathrm{m}^{3}$ are characterized by much lower heat conductivity coefficient than $\mathrm{OSB} / 3$ boards of the same

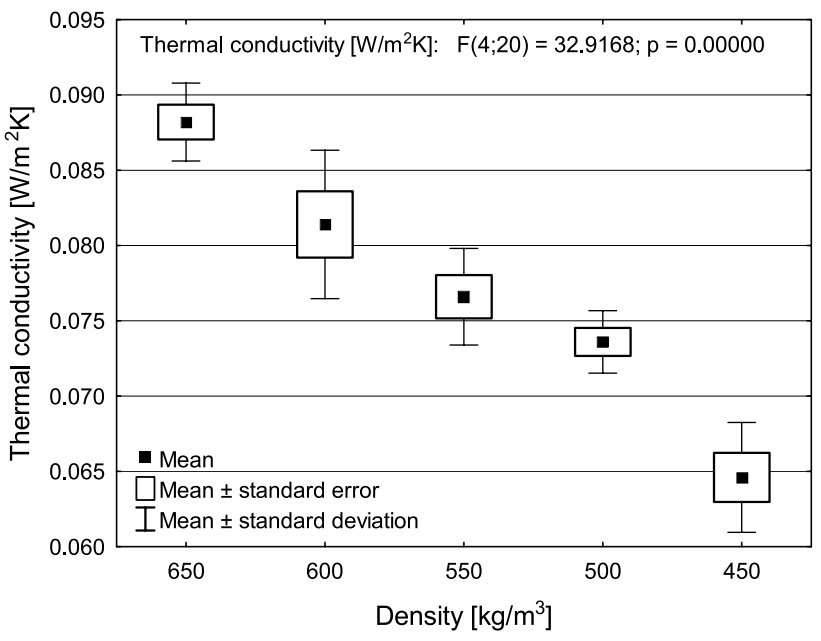

Fig. 2 Thermal conductivity coefficient for rapeseed particleboards (RPB) depending on their density

density, which are commonly used in building construction. With the use of the same measuring method, value of $\lambda$ for OSB $/ 3$ boards is determined as $0.11 \mathrm{~W} / \mathrm{mK}$, and for MFP it is $0.14 \mathrm{~W} / \mathrm{mK}$. These values are slightly different to those stated by the manufacturer, i.e. 0.13 and $0.12 \mathrm{~W} /$ $\mathrm{mK}$, respectively. Nevertheless, the values of heat conductivity coefficient for OSB/3 provided in literature are even lower: 0.098-0.106 W/mK (Sonderegger and Niemz 2009). Therefore it can be concluded that the produced rapeseed particleboards with a density of $650-550 \mathrm{~kg} / \mathrm{m}^{3}$ not only meet the strict requirements for construction boards, but they are characterized by better heat-insulating properties than particleboards. For rapeseed particleboards with the lowest density, i.e. $450 \mathrm{~kg} / \mathrm{m}^{3}$, the $\lambda$ coefficient is at a comparable level or slightly lower than for light particleboards or fibreboards produced from waste from other annual plants. However, most works published so far state that the boards had considerably lower density. For example, Ihnát et al. (2015) and Ihnát and Lübke (2015) determined the thermal insulation of fibreboards with a density of $250 \mathrm{~kg} /$ $\mathrm{m}^{3}$, including various amounts of wheat straw. The value of $\lambda$ coefficient varied from 0.050 to $0.064 \mathrm{~W} / \mathrm{mK}$. Similar results were obtained for boards of the same density made from rice straw- $\lambda=0.051 \mathrm{~W} / \mathrm{mK}$ (Wei et al. 2015). Yet, boards made from kenaf with even lower density of $200 \mathrm{~kg} / \mathrm{m}^{3}$ were characterized by $\lambda$ varying from 0.04 to $0.065 \mathrm{~W} / \mathrm{mK}$ (Xu et al. 2004). The investigated rapeseed particleboards with a density from 500 to $600 \mathrm{~kg} / \mathrm{m}^{3}$ are comparable with boards with a density of $535-682 \mathrm{~kg} / \mathrm{m}^{3}$ made from sunflower husk: the value $\lambda$ varied from 0.075 to $0.079 \mathrm{~W} / \mathrm{mK}$ (Evon et al. 2014; Cosereanu et al. 2015). Obviously, boards with lower density are characterized by less coherent structure. The decrease in density results in a 
larger amount of void spaces filled with air which, if dry, is a very good thermal insulator.

The use of wood based materials for building structures imposes considerable limitations to finishing works which contribute to increasing humidity level of the interior. However, while a building is used a large amount of moisture, such as vapour, is emitted and affects the insulation properties of walls, durability of materials the construction elements are made from and microclimate of the rooms. Taking the above into account, the sorption properties of the manufactured experimental rapeseed particleboards were determined. Figure 3 shows vapour sorption isotherms of the investigated particleboards depending on their density. Based on that, it can be concluded that the course of the sorption isotherm is similar for all the boards regardless of their density. It can only be noticed that for boards of higher density the sorptive humidity values were slightly lower than for boards with lower density, i.e. $450 \mathrm{~kg} / \mathrm{m}^{3}$. This trend is compliant with earlier studies conducted by $\mathrm{Wu}$ and Ren (2000) and Ganer et al. (2003). They showed that the effect of density on equilibrium moisture content value can only be seen at higher levels of relative humidity of the air, i.e. $85-100 \%$, which is also confirmed by the current studies. The phenomenon results from the fact that boards with lower density have more void spaces which can absorb water (Wu and Ren 2000), and the coherent structure of the boards with higher density restrains vapour penetration into the core of the board. To attain full characteristics of the investigated rapeseed particleboards, the sorption and desorption processes of the RPB and commercially produced wood-based boards, i.e. $\mathrm{OSB} / 3$ and MFP, were also compared. For investigation of this kind rapeseed particleboards were selected with a density of $600 \mathrm{~kg} / \mathrm{m}^{3}$, whose strength properties meet the requirements for wood-based particleboards. OSB $/ 3$ and MFP boards are very different to rapeseed particleboards in terms of the kind and fragmentation level of the raw material, the structure, density profile and technological parameters. Yet, the fact has been taken into account that out of all the construction boards, these boards are most commonly used in wooden building constructions.

In the literature on the subject, there are very few publications describing sorption properties of boards made from annual plant waste which can be used as reference. The works published so far refer mainly to the sorption properties of wood, and as for wood-based material they deal with OSB and particleboards ( $\mathrm{Wu}$ and Ren 2000; Hartley et al. 2007; Moya et al. 2009; Bonigut et al. 2014; Mendes et al. 2014 a, b; Vololonirina et al. 2014; Derkowski et al. 2015). However, based on the quoted literature and isotherms presented in Fig. 4 it was found that considerable differences in the sorption properties of OSB/3, MFP and rapeseed particleboards can be noticed when the relative humidity of the air is over $45 \%$. The average values of sorption humidity measured at 65 and $85 \%$ of relative humidity amount to, respectively, 11.0 and $19.8 \%$ for RPB, 9.6 and $15.6 \%$ for OSB and 8.47 and $14.11 \%$ for MFP. The values obtained for OSB are compatible with values determined by $\mathrm{Wu}$ and Ren (2000) and Hartley et al. (2007). The processes of water vapour desorption proceed in a similar way. Based on the attained date, it can be inferred that rapeseed particleboards are characterized by lower sorption humidity in the area of free water in the void spaces of the board. The described dissimilarities supposedly result from the different structure of commercially manufactured boards and rapeseed particleboards. Unlike rapeseed particleboards, OSB boards have three-layer structure with a

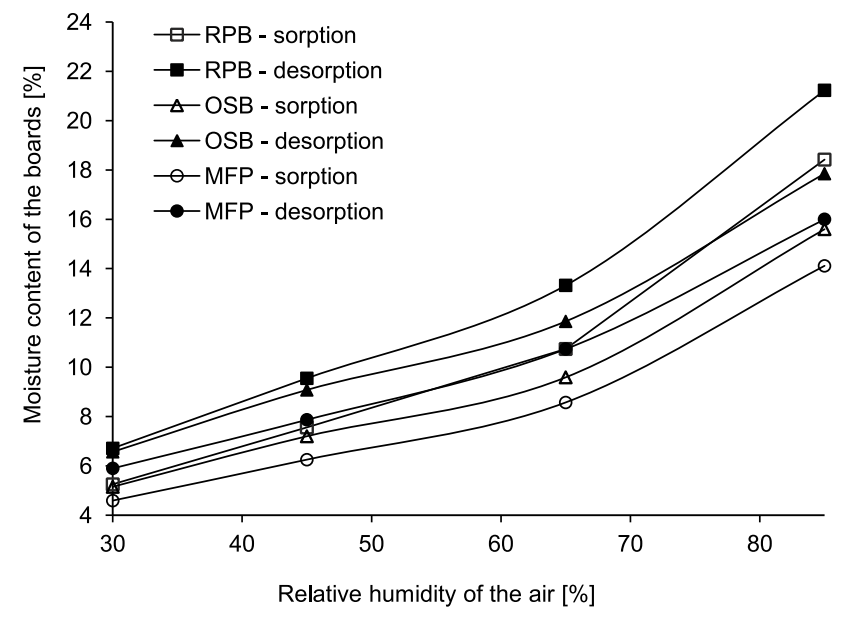

Fig. 4 Sorption-desorption isotherm of rapeseed particleboards (RPB) with a density of $600 \mathrm{~kg} / \mathrm{m}^{3}, \mathrm{OSB} / 3$ and MFP boards ing on their density
Fig. 3 Sorption isotherm of rapeseed particleboards (RPB) depend-

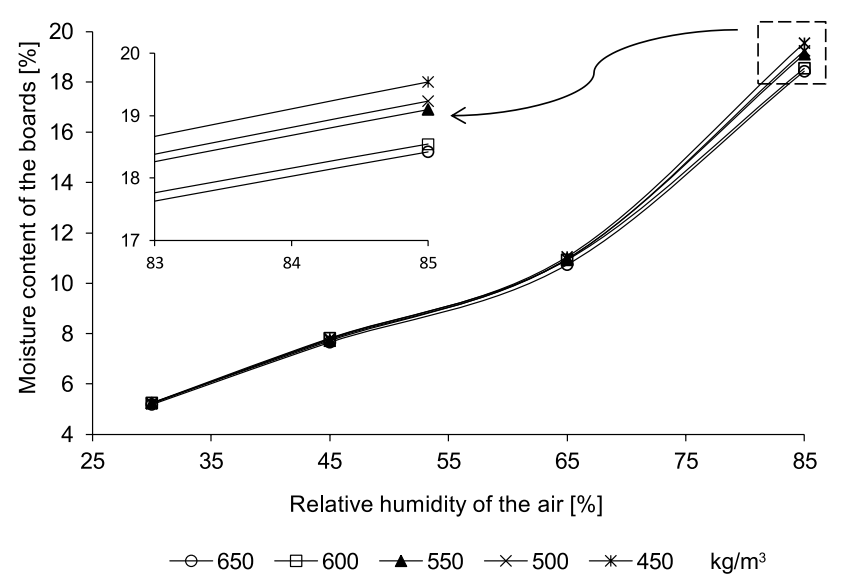

(a)


different density profile. The face layers of higher density not only improve the modulus of rupture and modulus of elasticity, but they efficiently reduce the penetration of vapour into the board. MPF boards are characterized by greater density than RPB. Moreover, the specific surface area of wood particles is larger than that of straw particles; consequently, the number of adhesive bonds is smaller. This fact as well as the anti-adhesive wax layer on the straw surface weaken the strength of the bond and deteriorate the resistance to long-lasting action of water.

In the literature, the differences between sorption and desorption isotherms of wood or wood-based panels in the same conditions of relative humidity are described as S/D ratio. The value of $S / D$ constant close to 1 indicates that the board is stable in the conditions of changeable humidity. Since the wood-based panels are susceptible to changes in humidity, it is essential to determine the S/D ratio (Hartley et al. 2007). The estimated S/D values for rapeseed particleboards in relation to OSB $/ 3$ and MFP, depending on the changes in relative humidity, are presented in Table 5. It shows that at the relative humidity level from 30 to $65 \%$ the rapeseed particleboards show S/D constant value similar to those attained for wood particleboards. Significant differences are noted when the relative humidity reaches $85 \%$. In such conditions, RPB boards show lower value of S/D ratio, which means they are more susceptible to changes in the humidity level than OSB and MFP.

\section{Conclusion}

These investigations lead to the conclusion that rapeseed straw particles are a valuable material, which can be used in the process of producing water-resistant particleboards to be applied not only to bio houses, whose structure is based on straw and fibrous materials, but also to eco-housing which is compatible with the idea of sustainable development. The obtained research results show that rapeseed straw can be used to produce construction particleboards with strength properties comparable to those

Table 5 S/D ratio calculated for rapeseed particleboards (RPB), $\mathrm{OSB} / 3$ and MFP boards

\begin{tabular}{|c|c|c|c|}
\hline \multirow[t]{2}{*}{ RH (\%) } & \multicolumn{3}{|l|}{$\mathrm{S} / \mathrm{D}$} \\
\hline & RPB* & $\mathrm{OSB} / 3$ & MFP \\
\hline 30 & 0.782 & 0.784 & 0.778 \\
\hline 45 & 0.792 & 0.793 & 0.790 \\
\hline 65 & 0.806 & 0.809 & 0.798 \\
\hline 85 & 0.868 & 0.877 & 0.882 \\
\hline
\end{tabular}

$R H$ relative humidity

*Density of boards-600 kg/m of particleboards type 5 and OSB/3 boards. The applied hybrid $\mathrm{pMDI} / \mathrm{PF}$ resin made it possible to decrease the density of the boards to $600-550 \mathrm{~kg} / \mathrm{m}^{3}$. Rapeseed particleboards meet the requirements for the boards of P5 and P3 type. Since the produced RPB boards have a singlelayer structure, they are more likely to swell in thickness. According to the determined value of thickness swelling after $24 \mathrm{~h}$ of soaking in water they can be classified as P3 type. Although those values are higher than those stated in the standard for type P5 particleboards, they are still comparable to the properties stated by producers of OSB/3 boards intended for universal use. In order to increase their water-resistance it would be advisable to apply hydrophobic agents, produce them as a three-layer structure (similarly to three-layer particleboards) or increase the fraction of pMDI in relation to PF resin. The worse resistance to humid conditions has also been confirmed by investigations on sorption and desorption of water vapour in changeable air humidity conditions. However, in comparison with particleboards, RPB boards are characterized by a lower heat conductivity coefficient. In practice, it means better thermal insulation and, as a result, reduced heat loss.

Acknowledgements We would like to express our gratitude to Marcin Kurpiński MSc for his help and support in implementing this research.

Open Access This article is distributed under the terms of the Creative Commons Attribution 4.0 International License (http:// creativecommons.org/licenses/by/4.0/), which permits unrestricted use, distribution, and reproduction in any medium, provided you give appropriate credit to the original author(s) and the source, provide a link to the Creative Commons license, and indicate if changes were made.

\section{References}

Arabi M, Faezipour M, Gholizadeh H (2011) Reducing resin content and board density without adversely affecting the mechanical properties of particleboard through controlling particle size. J Forest Res 22:659-664

Azizi K, Tabarsa T, Ashori A (2011) Performance characterizations of particleboards made with wheat straw and waste veneer splinters. Compos Part B 42(7):2085-2089

Bekalo SA, Reinhardt HW (2010) Fibers of coffee husk and hulls for the production of particleboard. Mater Struct 43(8):1049-1060

Bekhta P, Korkut S, Hiziroglu S (2013) Effect of pretreatment of raw material on properties of particleboard panels made from wheat straw. BioResources 8(3):4766-4774

Bonigut J, Krug D, Stuckenberg P (2014) Dimensional stability and irreversible thickness swell of thermally treated oriented strandboards (OSB). Eur J Wood Prod 72:593-599

Boquillon N, Elbez G, Schönfeld U (2004) Properties of wheat straw particleboards bonded with different types of resin. J Wood Sci 50(3):230-235

Conner AH, Lorenz LF, Kolby KC (2002) Accelerated cure of phenol-formaldehyde resins: studies with model compounds. J Appl Polym Sci 8:3256-3263 
Cosereanu C, Brenci LM, Zeleniuc O, Fotin A (2015) Effect of particle size and geometry on the performance of single-layer and three-layer particleboard made from sunflower seed husks. BioResources 10(1):1127-1136

Derkowski A, Mirski R, Majka J (2015) Determination of sorption isotherms of scots pine (Pinus Sylvestris L.) wood strands loaded with melamine-urea-phenol-formaldehyde (MUPF) resin. Wood Res 60(2):201-210

Dukarska D, Łęcka J (2006) Optimization of the process of pressing particleboards by means of modifying phenol-formaldehyde resin with amide polymers. Holz Roh- Werkst 64(5):403-409

Dukarska D, Łecka J, Szaforni K (2011) Straw of white mustard (Sinapis alba) as an alternative raw material in the production of particle boards resinated with UF resin. Silv Colendar Rat Ind Lignar 10(1):21-28. http://www.forestry.actapol.net/ pub/3_1_2011.pdf. Accessed 13 July 2016

Dukarska D, Łęcka J, Czarnecki R (2012) The effect of wood chip substitution with evening primrose waste on properties of particleboards depending on the type of binding agent. EJPU 15(2):05. http://www.ejpau.media.pl/articles/volume15/issue2/ art-05.pdf. Accessed 13 July 2016

Dukarska D, Bartkowiak M, Stachowiak-Wencek A (2015) White mustard straw as an alternative raw material in the manufacture of particleboards resinated with different amount of urea formaldehyde resin. Drewno 58(194):49-63

Dziurka D, Mirski R (2013) Lightweight boards from wood and rapeseed straw particles. Drewno 56(190):19-31

Dziurka D, Mirski R, Łęcka J (2005) Properties of boards manufactured from rapeseed straw depending on the type of the binding agent. EJPAU 8b(3):5. http://www.ejpau.media.pl/volume8/ issue 3/art-05.html. Accessed 13 July 2016

EN 310 (1993) Wood based panels. Determination of modulus of elasticity in bending and of bending strength. European Committee for Standardization, Brussels

EN 312 (2005) Particleboards-specifications. European Committee for Standardization, Brussels

EN 317 (1993) Particleboards and fiberboards. Determination of swelling in thickness after immersion in water. European Committee for Standardization, Brussels

EN 319 (1993) Determination of tensile strength perpendicular to the plane of the board. European Committee for Standardization, Brussels

Evon P, Vandenbossche V, Pontalier P, Rigal L (2014) New thermal insulation fiberboards from cake generated during biorefinery of sunflower whole plant in a twin-screw extruder. Ind Crop Prod $52: 354-362$

FAOSTAT (2016) FAO Statistics Division Available from: http:// faostat3.fao.org/download/Q/QC/E. Accessed 13 July 2016

Ganer S, Cloutier A, Beauregard R, Gendron G (2003) Effect of panel moisture content and density on moisture movement in MDF. Wood Fiber Sci 35(1):62-82

Goodhew S, Griffiths R (2005) Sustainable earth walls to meet the building regulations. Energy Build 37:451-459

Grigoriou AH (2000) Straw-wood composites bonded with various adhesive systems. Wood Sci Technol 34(4):355-365

Guler C, Sahin HI, Yeniay S (2016) The potential for using corn stalks as a raw material for production particleboard with industrial wood chips. Wood Res 61(2):299-306

Guuntekin E, Uner B, Karakus B (2009) Chemical composition of tomato (Solanum lycopersicum) stalk and suitability in the particleboard production. J Environ Biol 30(5):731-734

Hartley ID, Wang S, Zhang Y (2007) Water vapor sorption isotherm modeling of commercial oriented strand panel based on species groups and resin type. Build Environ 42:3655-3659

Hein PRG, Campos ACM, Mendes RF, Mendes LM, Chaix G (2011) Estimation of physical and mechanical properties of agro-based particleboards by near infrared spectroscopy. Eur J Wood Prod 69(3):431-442

http://www.pfleiderer.pl, http://www.pfleiderer.pl/constructionchipboard-premium-board-mfp-p5. Accessed 13 July 2016

Ihnát V, Lübke H (2015) Straw pulp as a secondary lignocellulosic raw material and its impact on properties of insulating fiberboards. Part II. Preparation of insulated fiberboards with straw content. Wood Res 60(2):235-246

Ihnát V, Borůka V, Babiak M, Lübke H, Schwartz J (2015) Straw pulp as a secondary lignocellulosic raw material and its impact on properties of insulating fiberboards. Part III. Preparation of insulated fiberboards from separately milled lignocellulosic raw materials. Wood Res 60(3):441-450

Kawasaki T, Kawai S (2006) Thermal insulation properties of wood-based sandwich panel for use as structural insulated walls and floors. J Wood Sci 52:75-83

Lee S, Shupe TF, Hse CY (2006) Mechanical and physical properties of agro-based fiberboard. Holz Roh- Werkst 64(1):74-79

Li XJ, Cai ZY, Winandy JE, Basta AH (2010) Selected properties of particleboard panels manufactured from rice straws of different geometries. Bioresour Technol 101(12):4662-4666

Lykidis C, Parnavela C, Goulounis N, Grigoriou A (2012) Potential for utilizing waste corrugated paper containers into wood composites using UF and PMDI resin systems. Eur J Wood Prod 70(6):811-818

Magzoub R, Osman Z, Tahir P, Nasroon TH, Kantner W (2015) Comparative evaluation of mechanical and physical properties of particleboard made from bagasse fibers and improved by using different methods. Cell Chem Technol 49(5-6):537-542

Mendes LM, Mendes SA, Mendes RF, Bufalino L, Protasio TD (2014a) Equilibrium moisture content of OSB panels made from eucalyptus urophylla clones. Cerne 20(4):519-528

Mendes LM, Mendes RF, Protasio TD, Oliveira SL, Mesquita RGD (2014b) Equilibrium moisture content of OSB panels produced veneer inclusion and different types of adhesive. Cerne 20(1):123-137

Mirski R, Dziurka D, Łęcka J (2008) Properties of phenol-formaldehyde resin modified with organic acid esters. J Appl Polym Sci 107(5):3358-3366

Mirski R, Dziurka D, Łęcka J (2011) Potential of shortening pressing time or reducing pressing temperature for plywood resinated with PF resin modified using alcohols and esters. Eur J Wood Prod 69(2):317-323

Mirski R, Derkowski A, Dziurka D (2013) Dimensional stability of OSB panels subjected to variable relative humidity: core layer made with fine wood chips. BioResources 8(4):6448-6459

Morel JC, Mesbah AM, Oggero MP, Walker P (2001) Building houses with local materials: means to drastically reduce the environmental impact of construction. Build Environ 36(10):1119-1126

Moya L, Tze WTY, Winandy JE (2009) The effect of cyclic relative humidity changes on moisture content and thickness swelling behavior of oriented strandboard. Wood Fiber Sci 41(4):447-460

Müller Ch, Schwarz U, Thole V (2012) Zur Nutzung von Agrar-Reststoffen in der Holzwerkstoffindustrie (On the utilization of agricultural residues in the wood-based panel industry) (In German). Eur J Wood Prod 70(5):587-594

Nemli G, Kirci H, Serdar B, Ay N (2003) Suitability of kiwi (Actinidia sinensis Planch.) prunings for particleboard manufacturing. Ind Crops Prod 17(1):39-46

Pan Z, Zheng Y, Zhang R, Jenkins BM (2007) Physical properties of thin particleboard made from saline eucalyptus. Ind Crop Prod 26(2):185-194

Papadopoulos AN, Hague JRB (2003) The potential for using flax (Linum usitatissimum L.) shiv as a lignocellulosic raw material for particleboard. Ind Crops Prod 17(2):143-147 
Papadopoulos AN, Hill CAS, Gkaraveli A, Ntalos GA, Karastergiou SP (2004) Bamboo chips (Bambusa vulgaris) as an alternative lignocellulosic raw material for particleboard manufacture. Holz Roh- Werkst 62:36-39

Park BD, Riedl B, Hsu EW, Shields J (1999) Differential scanning calorimetry of phenol-formaldehyde resins cure-accelerated by carbonates. Polymer 40:1689-1699

Park HJ, Oh SW, Wen MY (2012) Manufacture and properties of Miscanthus-wood particle composite boards. J Wood Sci 58(5):459-464

Sonderegger W, Niemz P (2009) Thermal conductivity and water vapour transmission properties of wood-based materials. Eur $\mathbf{J}$ Wood Prod 67(3):313-321

Thomson A, Walker A (2014) Durability characteristics of straw bales in building envelopes. Constr Build Mater 68:135-141

Van Duren I, Voinov A, Arodudu O, Firrisa T (2015) Where to produce rapeseed biodiesel and why? Mapping European rapeseed energy efficiency. Renew Energy 74:49-59

Vejeliene J, Gailius A, Vejelis S, Vaitkus S, Balciunas G (2011) Development of thermal insulation from local agricultural waste. In: the 8th international conference, 19-20 May, Vilinius, Lithuania. Environmental Engineering 1-3:437-440

Vololonirina O, Coutand M, Perrin B (2014) Characterization of hygrothermal properties of wood-based products-Impact of moisture content and temperature. Constr Build Mater 63:223-233

Wang SY, Yang TH, Lin LT, Lin CJ, Tsai MJ (2007) Properties of low-formaldehyde-emission particleboard made from recycled wood-waste chips sprayed with PMDI/PF resin. Build Environ 42(7):2472-2476

Wang SY, Yang TH, Lin LT, Lin CJ, Tsai MJ (2008) Fire-retardanttreated low-formaldehyde-emission particleboard made from recycled wood-waste. Bioresour Technol 99(6):2072-2077

Wei K, Lv Ch, Chen M, Zhou X, Dai Z, Shen D (2015) Development and performance evaluation of on a new thermal insulation material from rice straw using high frequency hot-pressing. Energy Build 87(1):116-122

Wu Q, Ren Y (2000) Characterization of sorption behavior of oriented strandboard under long-term cyclic humidity exposure condition. Wood Fiber Sci 32(4):404-418

Xu J, Sugawara R, Widyorini R, Han G, Kawai S (2004) Manufacture and properties of low-density binderless particleboard from kenaf core. J Wood Sci 50:62-67

Yu ZT, Xu X, Fan LW, Hu YC, Cen KF (2011) Experimental measurements of thermal conductivity of wood species in China: effects of density, temperature, and moisture content. Forest Prod J 61(2): 130-135

Zhang L, Hu YC (2014) Novel lignocellulosic hybrid particleboard composites made from rice straws and coir fibers. Mater Des 55:19-26

Zhang W, Ma YF, Wang CP, Li SH, Zhang MM, Chu FX (2013) Preparation and properties of lignin-phenol-formaldehyde resins based on different biorefinery residues of agricultural biomass. Ind Crop Prod 43:326-333 